Mariusz Granosik*

Anita Gulczyńska*

Małgorzata Kostrzyńska*

\title{
Międzynarodowa konferencja “Participatory Social Work: Approaches, Barriers, Critique", Łódź 29-30 września 2016 r.
}

W dniach 29-30 września 2016 r. na Wydziale Nauk o Wychowaniu Uniwersytetu Łódzkiego odbyła się międzynarodowa konferencja "Participatory Social Work: Approaches, Barriers, Critique", zorganizowana przez Katedrę Pedagogiki Społecznej oraz European Research Institute for Social Work (ERIS).

Konferencję uroczyście otworzył Wiceprezydent Łodzi Tomasz Trela oraz Dziekan Wydziału Nauk o Wychowaniu UŁ Danuta Urbaniak-Zając. W sesjach plenarnych swoje prezentacje przedstawili: Peter Beresford (Brunel University, UK), Jean-Marie Barbier (Chaire Unesco Formation et Pratiques Professionnnelles du Cnam, Paris, FR), Marek Czyżewski (Uniwersytet Łódzki) oraz Ewa Marynowicz-Hetka (Uniwersytet Łódzki), ponadto wygłoszono 35 wystąpień w siedmiu grupach tematycznych oraz zaprezentowano 12 posterów. Ogółem w konferencji wzięło udział ponad 100 uczestników - badaczy, nauczycieli, studentów oraz praktyków w obszarze pracy socjalnej - reprezentujących: Polskę, Austrię, Republikę Czeską, Słowację, Niemcy, Wielką Brytanię, Finlandię, Francję, Węgry, Włochy, Litwę, Belgię, Indie.

Jednym z kluczowych punktów programu była trójstronna wideokonferencja z Chicago Loyola University School of Social Work i Uniwersytetem Witolda Wielkiego z Kowna. Katherine Tyson (Loyola University Chicago, USA) oraz Jonas Ruškus (Katedra Pracy Socjalnej, Vytautas Magnus University, Litwa) wspólnie ze studentami zaprezentowali autorską koncepcję kształcenia do partycypacyjnej pracy socjalnej. Prowadzony przez nich program obejmuje cotygodniowe zajęcia $\mathrm{w}$ formie dwustronnej wideokonferencji, w przebiegu których partnerzy wymieniają się doświadczeniami z partycypacyjnych projektów socjalnych, realizowanych

* Katedra Pedagogiki Społecznej,Uniwersytet Łódzki. 
przez grupy studentów w obu krajach. Oprócz poznania założeń i celów tego programu kształcenia uczestnicy konferencji mieli szansę zapoznać się z imponującym projektem międzypokoleniowego mentoringu (cross-age mentoring program) prowadzonym przez studentów amerykańskich z udziałem młodzieży ze zubożałych sąsiedztw chicagowskich, który miał służyć m.in. wzmocnieniu „sprężystości” (resilience) studentów-mentorów i ich młodszych kolegów z sąsiedztw, zbudowaniu alternatywnej sieci relacji społecznych oraz rozbudzeniu u uczestników sił potrzebnych do pokonywania obciążeń socjalizacji w takich sąsiedztwach. Szczególne wrażenie na uczestnikach wideokonferencji wywarło zaangażowanie amerykańskich studentów na etapie tworzenia samego projektu, jak i w przebiegu dyskusji z uczestnikami konferencji. Profesor Jonas Ruškus, będący członkiem Komitetu Praw Osób Niepełnosprawnych przy ONZ, podzielił się ponadto swoimi spostrzeżeniami na temat znaczenia partycypacyjnych badań w działaniu dla zmiany społecznej służącej przestrzeganiu praw człowieka w obszarze niepełnosprawności.

W dniu przed rozpoczęciem konferencji oraz w dniu po oficjalnym zamknięciu jej akademickiej części uczestnicy mieli możliwość odwiedzenia łódzkich instytucji, realizujących różne formy partycypacyjnej pracy społecznej. Goście między innymi mogli poczuć, w jakiej sytuacji na co dzień znajdują się osoby głuchoniewidome poprzez udział w specjalnie przygotowanych symulacjach oraz poznać działania podejmowane przez pracowników Centrum Edukacji i Aktywizacji Zawodowej Osób Niepełnosprawnych. Ponadto zapoznali się z funkcjonowaniem Ośrodka Szkoleniowego „Kłos” prowadzącego Zakład Aktywizacji Zawodowej dla osób przeżywających zaburzenia psychiczne (działania z zakresu ekonomii społecznej). Wizyty w przywołanych instytucjach zainicjowały dyskusję nad różnicami i podobieństwami rozwiązań przyjmowanych w różnych krajach.

Problematyka partycypacyjnej pracy socjalnej oraz tak zorientowanych badań nie jest często podejmowana w polskim dyskursie akademickim, rzadko również pojawia się w bardziej usystematyzowany sposób w działaniach praktyków. Niewątpliwa popularyzacja samego terminu „partycypacja” , która jest efektem priorytetów UE i wpisujących się w te priorytety programów, nie zawsze skutkuje dogłębną i krytyczną refleksją nad działaniami mającymi w zamiarze wzmocnić uczestnictwo wszystkich stron zaangażowanych w pracę socjalną. W tej perspektywie, jednym $\mathrm{z}$ istotniejszych efektów naukowych konferencji było wsparcie (a niekiedy nawet zainicjowanie) dyskursu nad partycypacyjnymi podejściami do badania i działania, poprzez stworzenie okazji spotkania orędowników i aktywistów podejść partycypacyjnych oraz krytyków tej orientacji. Pozostaje mieć nadzieję, że dyskusja nad uczestnictwem użytkowników, wychowanków, domowników czy klientów w działaniach, które bezpośrednio ich dotyczą, będzie kontynuowana, a jej efekty znajdą swoją aplikację choćby na niektórych polach polskiej pracy socjalnej. 